Article

\title{
Precipitation Intensity Effects on Groundwater Recharge in the Southwestern United States
}

\author{
Brian F. Thomas ${ }^{1, *}$, Ali Behrangi ${ }^{1}$ and James S. Famiglietti ${ }^{1,2,3}$ \\ 1 Jet Propulsion Laboratory, California Institute of Technology, Pasadena, CA 91109, USA; \\ Ali.Behrangi@jpl.nasa.gov (A.B.); James.Famiglietti@jpl.nasa.gov (J.S.F.) \\ 2 Department of Earth System Science, University of California, Irvine, CA 92697, USA \\ 3 Department of Civil and Environmental Engineering, University of California, Irvine, CA 92697, USA \\ * Correspondence: Brian.F.Thomas@jpl.nasa.gov; Tel.:+1-818-354-3886
}

Academic Editors: Magaly Koch and Thomas M. Missimer

Received: 27 December 2015; Accepted: 29 February 2016; Published: 8 March 2016

\begin{abstract}
Episodic recharge as a result of infrequent, high intensity precipitation events comprises the bulk of groundwater recharge in arid environments. Climate change and shifts in precipitation intensity will affect groundwater continuity, thus altering groundwater recharge. This study aims to identify changes in the ratio of groundwater recharge and precipitation, the R:P ratio, in the arid southwestern United States to characterize observed changes in groundwater recharge attributed to variations in precipitation intensity. Our precipitation metric, precipitation intensity magnification, was used to investigate the relationship between the R:P ratio and precipitation intensity. Our analysis identified significant changes in the R:P ratio concurrent with decreases in precipitation intensity. The results illustrate the importance of precipitation intensity in relation to groundwater recharge in arid regions and provide further insights for groundwater management in nonrenewable groundwater systems and in a changing climate.
\end{abstract}

Keywords: groundwater recharge; precipitation intensity; climate change; sustainable groundwater management

\section{Introduction}

Sustainable groundwater management requires an effective framework that includes, in part [1], an understanding of groundwater system fluxes. Challenges to sustainable groundwater management are directly linked to the estimation of outflow (i.e., pumping, baseflow) and inflow (i.e., recharge) [2] and are thus linked to the flux of water that infiltrates to the saturated zone. As described by Theis [3], the rate of groundwater recharge is dependent upon the rate of the addition of water to the system and the rate at which available water can infiltrate to a depth thus escaping evaporation. Throughout the world, groundwater depletion has spurred actions which include recharge augmentation such as importing surface water [4] and rainwater capture [5]. The volume of recharge to an aquifer system alone does not correspond to the portion of available groundwater storage for withdrawals. Such an antiquated idea, conceptualized as safe yield [6,7], was replaced by sustainable groundwater management theories which account for ecosystem services provided by groundwater storage including baseflow to streams [8] and the maintenance of groundwater storage.

Global observations and groundwater simulations have evaluated changes to recharge based on IPCC projections $[9,10]$ or have evaluated groundwater recharge to assess resilience [11]. Model-based approaches $[9,12-17]$ range from simplistic soil budget models to fully coupled global climate models and groundwater flow models to study groundwater recharge. Such approaches typically seek to determine long-term groundwater recharge as a function of changes in precipitation intensity and timing. 
Groundwater recharge is an important variable for effective groundwater management $[1,6,10]$, especially in arid regions with little recharge [11,18]. Groundwater resources in arid environments have been identified as under stress resulting from the imbalance between groundwater recharge and the combination of natural rates of discharge and groundwater withdrawals. Groundwater storage in arid regions is considered non-renewable [18,19] at timescales of groundwater management planning horizons and are often impacted by anthropogenic activities resulting in dramatic changes in groundwater resources [20]. An example illustrating the influence of anthropogenic impacts to natural aquifer discharge rates is the Nubian aquifer in northeast Africa: prior to extensive development, studies documented the natural rate of groundwater depletion of $0.79 \mathrm{~km}^{3} /$ year [21] to $2.7 \mathrm{~km}^{3}$ /year [22] while more recent depletion rates of $6.1 \mathrm{~km}^{3} /$ year have been observed from 2003 to 2013 [11]. Future imbalances of groundwater recharge are expected to occur as a result of variability attributed to climate change, especially in arid regions [9,23].

In arid and semi-arid environments, groundwater recharge tends to occur during extreme precipitation events [24] as compared to other environments which are characterized as having a combination of constant-rate and episodic behaviors [25]. Groundwater recharge varies spatially as a result of physical attributes including soil type, depth to groundwater, vadose zone porosity, hydrogeology and precipitation patterns. Because of the episodic nature of recharge in arid environments, small changes in precipitation intensity have been suggested to influence groundwater recharge [26,27]. Recent studies have sought to quantify episodic recharge [28] or identify regional groundwater recharge $[10,11,23]$. Such evaluations, however, did not identify influences in observed groundwater recharge as a function of precipitation, the primary goal of this study.

The arid southwestern United States has experienced prolonged drought conditions [29,30]. Castle et al. [31] evaluated groundwater storage changes during the drought and identified significant groundwater depletion in the Lower Colorado River Basin. In that study, the authors attributed significant changes of groundwater depletion rates to discrepancies between surface water (i.e., reservoirs) and groundwater management resulting from the drought. Alley and Konikow [32] argue that a portion of the groundwater storage declines may result from natural groundwater discharges. In reality, the likely scenario of groundwater storage loss in the region includes a combination anthropogenic influences, natural groundwater discharges and climate. In this study, we seek to evaluate changes in the ratio of recharge to precipitation (R:P ratio) which may account for rates of groundwater declines observed in the region. For example, changes in recharge to the aquifers may result in short-term fluctuations in both natural and anthropogenic fluxes from the aquifer [33]. Our evaluation holds important implications for groundwater management in arid environments as groundwater resources are used to meet more than $70 \%$ of water demands [34] while climate projections predict reduced precipitation in arid regions [35]. In our study, we evaluate changes in the R:P ratio using a double mass curve approach [26,36] in combination with satellite-observed precipitation data to attribute changes in precipitation statistics to observed changes in groundwater recharge at locations across the arid southwestern United States (Figure 1). 


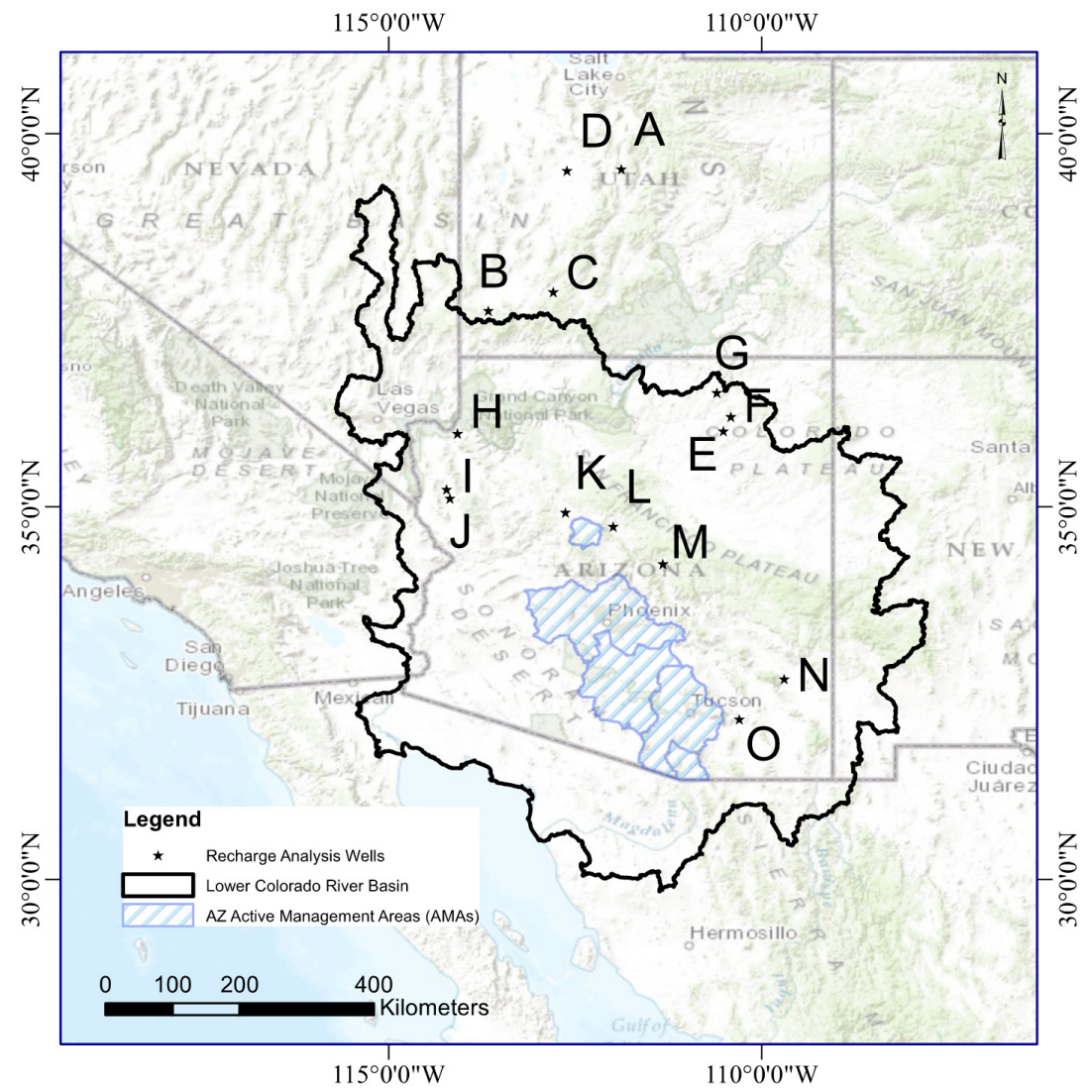

Figure 1. Site map illustrating locations of groundwater observation wells.

\section{Data}

\subsection{TRMM}

Data from the latest version of the Tropical Rainfall Measuring Mission (TRMM) merged precipitation product (3B42-V7; [37]) was used to account for precipitation rates within the 0.25-degree grid surrounding each groundwater observation with a focus on the period 2000-2015. The TRMM product is bias adjusted using monthly ground gauge data from the Global Precipitation Climatology Centre (GPCC) product [38]. The 3-h, 0.25-degree product has been found valuable for hydrologic modeling (e.g., [39]) and successfully applied in the southwestern United States to assess monsoon precipitation behavior $[40,41]$.

\subsection{Groundwater Hydrographs}

Observations of water table depth were collected from the U.S. Geological Survey (USGS) [42] and the Arizona Department of Water Resources (ADWR) [43]. Well locations as illustrated in Figure 1 were selected based on length and completeness of record, time between observations (15-min to 6-h intervals) and for geographical representation throughout the study region. Wells within Active Management Areas in Arizona were not included in our study as groundwater replenishment activities are often used to augment groundwater resources.

\subsection{USGS Streamflow Data}

Streamflow data from USGS gages [42] were collected for watersheds either in near proximity to or enveloping groundwater observation wells. Gage stations were selected for sites with fewer than 5 consecutive days of no flow readings and a maximum of $5 \%$ missing data. Hydrograph recessions were isolated by identifying the beginning of a streamflow recession when a 3-day moving average begins to decrease and ends when a 3-day moving average begins to increase [44,45]. 


\section{Methods}

\subsection{Estimation of Recharge}

The estimation of groundwater recharge using in situ data can be conducted using multiple approaches, including the water table fluctuation (WTF) method [46] and the master recession curve (MRC) approach [47]. One would anticipate that in arid environments, groundwater elevations would typically be in a near steady-state decline over time due to the natural recession behavior of aquifer systems without external influences (i.e., pumping) [3]. Periodic recharge would occur during this natural recession decline as a result of intense precipitation events. The MRC approach of [47] is thus advantageous in our evaluation of recharge as the analysis accounts for natural and anthropogenic changes in groundwater hydrograph recessions over time.

The MRC approach provided as an executable program [47] was used to isolate groundwater recharge for select wells in the arid southwestern US (Figure 1) while accounting for rates of decline in observed groundwater elevation data. The MRC approach is an extension of the WTF method which estimates groundwater recharge as a function of water table height with respect to water table elevation which would occur in the absence of recharge $\left(\Delta H_{t}\right)$. Groundwater recharge for each time step $\mathrm{t}\left(R_{\mathrm{t}}\right)$ is calculated by

$$
R_{t}=S_{y} \times \Delta H_{t}
$$

where $S_{\mathrm{y}}$ is the specific yield. As described by [47], a limitation of the MRC approach is the estimate of the specific yield; thus, recharge was only estimated at wells for which a robust estimate of specific yield could be identified using a relation between streamflow and groundwater elevations [48]. As described by [49], one may estimate specific yield $\left(S_{\mathrm{y}}\right)$ as

$$
S_{y}=\frac{q}{\Delta h}
$$

where $q$ represents the average streamflow during a hydrograph recession event as a depth per unit of catchment area and $\Delta h$ represents the average decline in groundwater elevations during the streamflow hydrograph recession period.

Nimmo et al. [28] extend the MRC approach to account for episodic recharge events. In that study, selected episodic recharge events from wells were used to estimate recharge. In our analysis, we wish to characterize a change in the relationship between recharge $(\mathrm{R})$ and precipitation $(\mathrm{P})$. Thus, we employ the MRC approach to produce a continuous time series of recharge estimates. The bin-averaged approach was used to isolate recharge in individual groundwater observation wells with recharge rates estimated at the same time interval as groundwater readings ( $\Delta \mathrm{t}=15 \mathrm{~min}$ to $6 \mathrm{~h}$ ). Because of the small $\Delta \mathrm{t}$ between observations, a large bin number was used $(n=1000)$ to ensure accurate representation of average groundwater elevation decline rates expressed in the MRC. Output from the MRC analysis includes an estimate of recharge, cumulative recharge and a representation of the groundwater hydrograph recession behavior used to construct the MRC for each individual well.

\subsection{Double Mass Curve}

The double mass curve (DMC) is a simple graphical method to evaluate the consistency of hydrological data $[36,50]$. The DMC approach plots the cumulative data of one variable against the cumulative data of a second variable. A break in the slope of a linear function fit to the data is thought to represent a change in the relation between the variables. This approach provides a robust method to determine a change in the behavior of precipitation and recharge in a simple graphical method. The DMC approach has been used to detect changes in the relation between groundwater recharge and precipitation [26] by plotting the sum of recharge against the sum of precipitation. Such an approach is used here since the change in the fraction of precipitation resulting in observed recharge at a well, the $\mathrm{R}: \mathrm{P}$ ratio, indicates a change in groundwater continuity [51]. 
To assess a change in the R:P ratio, we use a single-phase regression (SPR) analysis. The parametric approach takes advantage of the optimal properties of linear regression whereby the paired time series $(\mathrm{RP})$ are divided into 2 groups $\left(R \mathrm{P}_{\mathrm{tc}}, \mathrm{RP}_{\mathrm{tn}}\right)$ given by

$$
\sum R_{t}=\left\{\begin{array}{c}
\beta_{O 1}+\beta_{1} \sum P_{t c}+\varepsilon_{t c} 1 \leqslant R_{t} \leqslant t_{c} \\
\beta_{O 2}+\beta_{2} \sum P_{t n}+\varepsilon_{t n} 1+t_{c} \leqslant R_{t} \leqslant t_{n}
\end{array}\right.
$$

where $t_{c}$ and $t_{n}$ represent the time at which the paired time series is split into 2 groups and $\beta_{1}$ and $\beta_{2}$ represent the slope between the sum of $R$ and the sum of P. The residuals given in Equation (3), $\varepsilon_{\mathrm{tc}}$ and $\varepsilon_{\mathrm{tn}}$, are correlated, an expected result given that the summed time series $R_{\mathrm{t}}$ and $P_{\mathrm{t}}$ are serially correlated, thus failing to meet requirements of ordinary least squares regression. For this analysis, we employed a bootstrap approach to estimate the coefficients $\beta_{1}$ and $\beta_{2}$ in addition to the coefficient standard error estimates $\left(\mathrm{S}_{\beta 1}\right.$ and $\left.\mathrm{S}_{\beta 2}\right)$. Our test statistic to identify a significant change of slope in the $\mathrm{R}: \mathrm{P}$ ratio, $T_{\mathrm{c}}$, is defined by

$$
T_{c}=\frac{\hat{\beta_{1}}-\hat{\beta_{2}}}{\sqrt{S_{\beta_{1}}^{2}-S_{\beta_{2}}^{2}}}
$$

Our statistic $T_{c}$ follows as student's $t$ distribution. Any reference to significant changes in the slope of R:P in our analysis implies a $p$-value $<0.001$ unless otherwise noted.

\subsection{Intensity-Duration-Frequency}

Intensity-duration-frequency (IDF) analysis provides a statistical graphical representation of rainfall intensity for a given exceedance probability [52,53]. Analyses of statistical precipitation events are often used in the design of engineering structures involving hydrologic flows [54] while statistical representations of IDF results have become commonplace in hydrology textbooks $[55,56]$. Creating IDF curves begins by isolating annual maximum precipitation depths for the duration of interest, and using a statistical distribution to identify precipitation intensities for specific return periods. The 3-h TRMM data for each groundwater well location was used to identify duration periods of 3, 6, 12, 24,36 and $48 \mathrm{~h}$ by summing precipitation depths over the time window of interest. As described by Stedinger et al. [50], the extreme value (EV) distributions are often used to fit observed hydrologic random variable behavior. The Gumbel distribution is one example of an EV distribution often used for rainfall [57] or floods [58,59]. Given a set of $X$-hour rainfall $\left(\mathrm{P}_{1}, \ldots, \mathrm{P}_{\mathrm{n}}\right)$, let the random variable $\mathrm{P}$ be the annual maximum of $P_{i}$, where $X$ represents the time window of interest. If $P$ are independent and identically distributed random variables with no upper bound, we can assume that $\mathrm{P}$ has a Gumbel distribution. Return intervals for annual maximum values of $\mathrm{P}$ can then be estimated using the Gumbel distribution given by the quantile function

$$
\chi_{p}=\varepsilon-\alpha \times \ln (\ln (-\mathrm{p}))
$$

for any probability $\mathrm{p}$ along with the first moment (i.e., mean) and second moment (i.e., variance)

$$
\begin{gathered}
\mu_{x}=\varepsilon+0.57721 \times \alpha \\
\sigma_{x}^{2}=\pi^{2} \alpha^{2} / 6
\end{gathered}
$$

where $\varepsilon$ and $\alpha$ in Equations (6) and (7) can be estimated using various approaches including L-moments [60] while probability $\mathrm{p}$ can be estimated using the Gringorten plotting position $(p=(\mathrm{i}-0.44) /(\mathrm{n}+0.12))$ where $\mathrm{i}$ represents rank and $\mathrm{n}$ is the number of observations. IDF analysis employing the Gumbel distribution provides a statistical graphical representation of rainfall intensity for a given exceedance probability [50,51]. IDF curves have been used to evaluate groundwater recharge [61-64] which may be impacted by changes in precipitation patterns as a result of climate change [35]. Of these studies, only Dourte et al. [61] evaluated IDF changes which may be related to deviations in groundwater recharge. 


\section{Results}

\subsection{Temporal Changes in Groundwater Elevations}

Groundwater hydrograph recession behaviors are captured in the predicted rate of decline of groundwater elevations, $\mathrm{dh} / \mathrm{dt}$, as estimated in the MRC recharge estimation approach. The data are used to create the master recession curve for each well, synonymous with master recession curves used to characterize streamflow hydrograph behavior [65,66]. Of interest is the general observance of groundwater elevations over time which are used to quantify groundwater recharge. An analysis was conducted using the SPR approach to identify a change in the behaviors of $\mathrm{dh} / \mathrm{dt}$ (Figure 2) by plotting the sum of $\mathrm{dh} / \mathrm{dt}$ against time. It is important to note that regions with little change in the cumulative sum of $\mathrm{dh} / \mathrm{dt}$ represent times during which recharge occurs, thereby negating decreases in $\mathrm{dh} / \mathrm{dt}$ over time. For wells located within the Lower Colorado River Basin (Figure 1), significant changes in groundwater behaviors where identified in the period ranging from August 2008 to July 2010, well within the timeframe identified by Castle et al. [31] who detected a significant change in groundwater storage behaviors using data from the Gravity Recovery and Climate Experiment (GRACE) satellites to isolate a groundwater storage time series. In that study, changes in groundwater storage were attributed to an intensification of the drought in 2012 and unsustainable groundwater withdrawals. Our results illustrated increased rates of groundwater storage depletion over time, thus corroborating the observed reductions in storage over the region [31,67]. The results illustrated in Figure 2 are important as the general increased rate of decline (i.e., active groundwater depletion) is accounted for in the estimate of groundwater recharge.
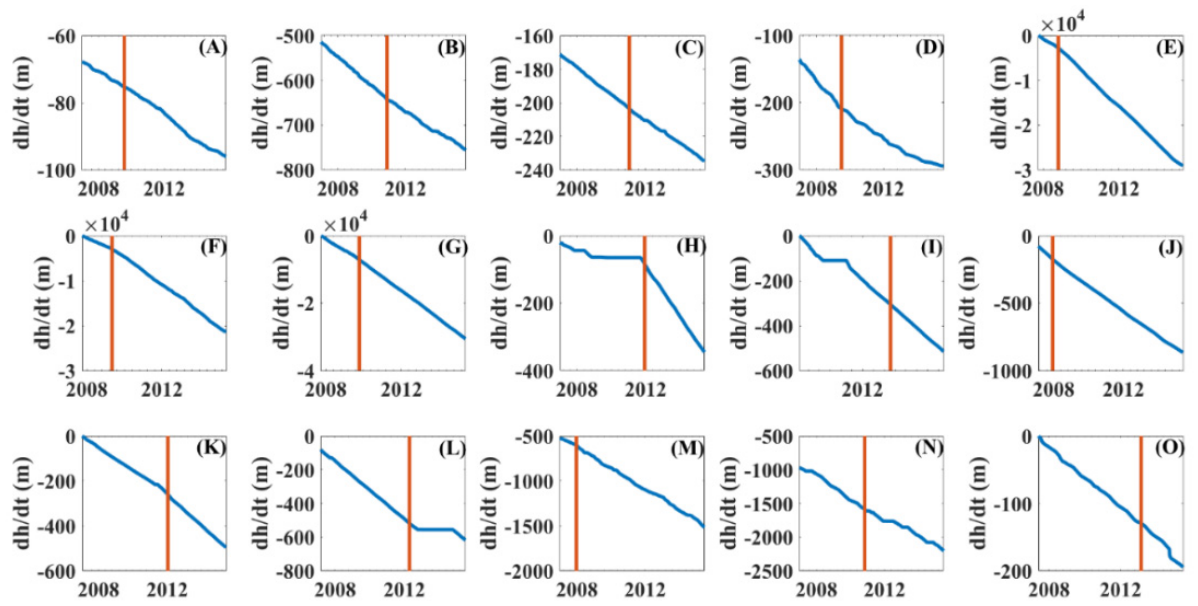

Figure 2. The cumulative rate of change in groundwater elevations ( $\mathrm{dh} / \mathrm{dt}$ ) (in blue) and the timing of the maximum $\mathrm{T}_{\mathrm{c}}$ statistic indicating a significant $(p<0.001)$ change in the behavior of $\mathrm{dh} / \mathrm{dt}$ (in orange). Panels correspond to wells identified in Table 1 and Figure 1.

Table 1. Well information.

\begin{tabular}{cccc}
\hline Well ID & Figure Label & GW Level $\Delta \mathbf{t}$ & R:P Date \\
\hline 393143111523301 & A & $6-\mathrm{h}$ & October 2007 \\
373735113394101 & $\mathrm{~B}$ & $6-\mathrm{h}$ & September 2007 \\
375244112463201 & $\mathrm{C}$ & $6-\mathrm{h}$ & July 2007 \\
393020112362201 & $\mathrm{D}$ & $6-\mathrm{h}$ & August 2008 \\
360055110304001 & $\mathrm{E}^{*}$ & $15-\mathrm{min}$ & April 2009 \\
361225110240701 & $\mathrm{~F}^{*}$ & $15-\mathrm{min}$ & April 2009 \\
363143110355001 & $\mathrm{G}^{*}$ & $15-\mathrm{min}$ & April 2009 \\
355855114043501 & $\mathrm{H}^{*}$ & $6-\mathrm{h}$ & November 2008 \\
\hline
\end{tabular}


Table 1. Cont.

\begin{tabular}{cccc}
\hline Well ID & Figure Label & GW Level $\Delta \mathbf{t}$ & R:P Date \\
\hline 351401114132401 & $\mathrm{I}^{*}$ & $6-\mathrm{h}$ & August 2010 \\
350633114103701 & $\mathrm{~J}^{*}$ & $6-\mathrm{h}$ & August 2009 \\
345524112374401 & $\mathrm{~K}^{*}$ & $6-\mathrm{h}$ & August 2010 \\
344359111591101 & $\mathrm{~L}^{*}$ & $6-\mathrm{h}$ & January 2009 \\
341402111215101 & $\mathrm{M}^{*}$ & $6-\mathrm{h}$ & August 2009 \\
324113109415401 & $\mathrm{~N}^{*}$ & $6-\mathrm{h}$ & September 2007 \\
320901110175301 & $\mathrm{O}^{*}$ & $6-\mathrm{h}$ & September 2008 \\
\hline
\end{tabular}

Note: The * identifies wells located within the Lower Colorado River Basin.

\subsection{Recharge}

Groundwater recharge as estimated from groundwater head changes, groundwater hydrograph recessions and estimated specific yield are illustrated in Figure 3 as monthly estimated recharge as a percent of precipitation. Differences in recharge between sites can be largely explained by variability in hydrogeological conditions including various depths to the potentiometric surface. The results in Figure 3 clearly illustrate the influence of summer monsoonal precipitation events which result in greater rates of recharge as a function of precipitation. The influence of the lag between observations of precipitation and the episodic recharge event in the potentiometric surface is also evident. For example, intense precipitation events were observed at Site A in October 2008 with negligible recharge in the groundwater hydrograph. However, in November 2008, despite little observed precipitation, a large recharge event was identified resulting from the time necessary to infiltrate through the vadoze zone and result in an observed change in groundwater storage in the well, thus causing a large apparent ratio between $\mathrm{R}$ and $\mathrm{P}$.
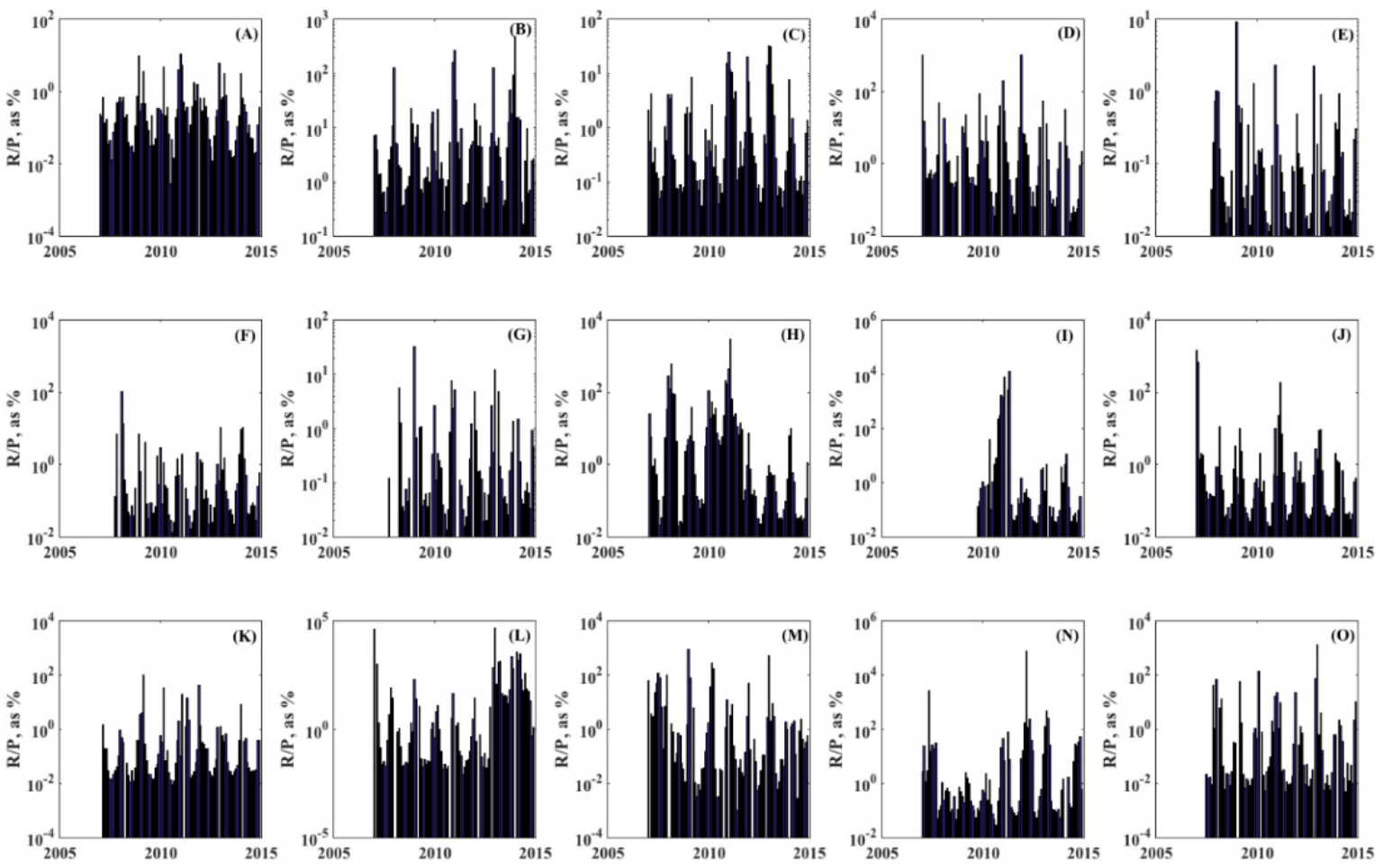

Figure 3. Monthly ratios of recharge $(\mathrm{R})$ to precipitation $(\mathrm{P})$. It is important to recognize the influence of infiltration lag, which produces high ratios of $\mathrm{R} / \mathrm{P}$ on a monthly time scale. 


\subsection{R:P Ratio}

The relation between precipitation and recharge is represented through the double mass curve (DMC) as illustrated in Figure 4. The episodic nature of recharge, depicted by a characteristic step pattern, is clearly evident for all sites. Sites with notable increased linearity in the DMC represent sites with larger recharge estimates (i.e., Figure 4e) [26]. Further, the timing of recharge estimated for the wells coincides with monsoonal precipitation events as depicted in Figure 3.
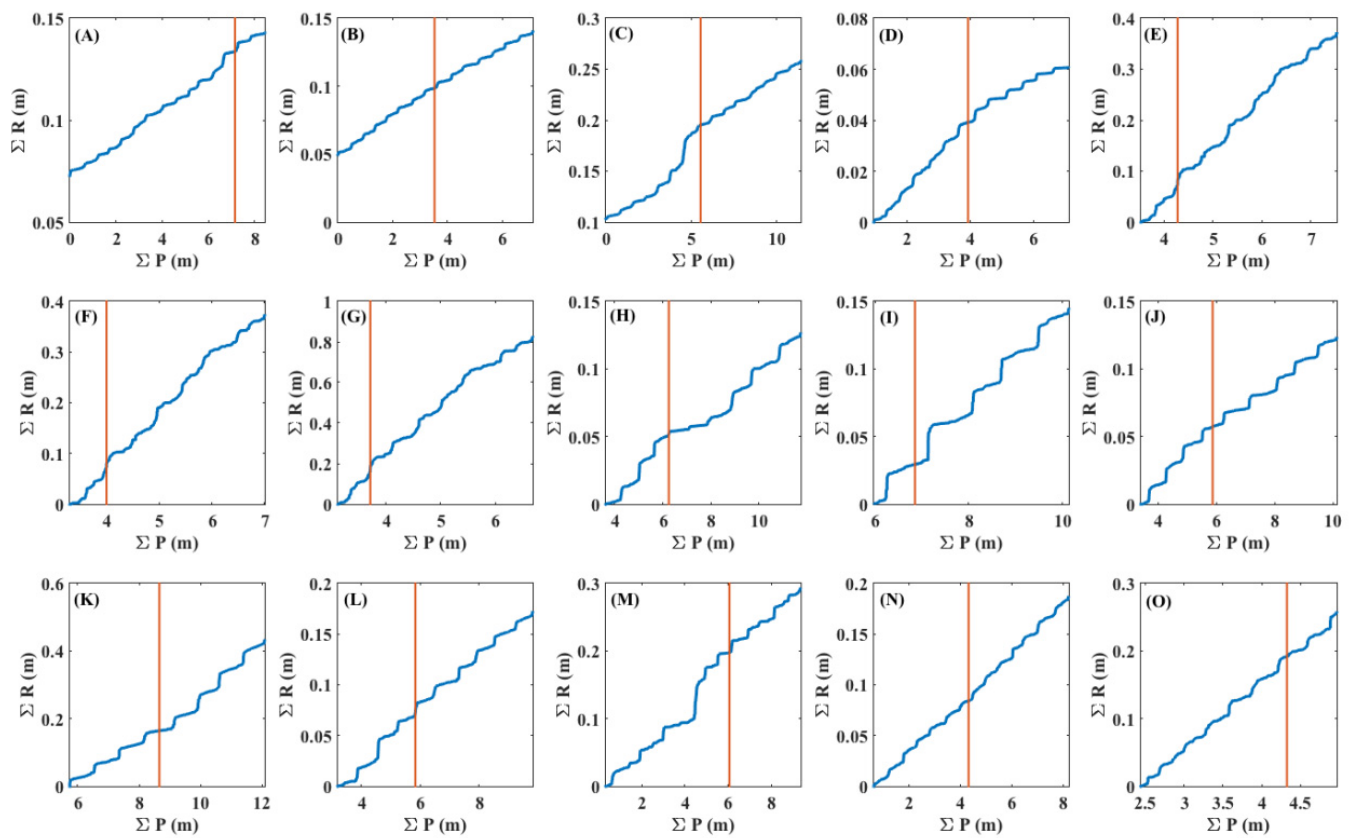

Figure 4. Double mass curves illustrating sum of precipitation $(\mathrm{P})$ versus sum of recharge (R). The significant change in the $\mathrm{R} / \mathrm{P}$ ratio is illustrated as a vertical orange line. The step pattern in the DMC is typical of episodic recharge.

The SPR approach was used to detect changes in the R:P ratio. The results illustrated in Figure 4 and summarized in Table 1 demonstrate that significant changes in slope were identified in all wells, with changes corresponding to dates ranging from July 2007 to August 2010. This significant change in slope suggests an imbalance in the physical recharge behaviors in the system. To evaluate the potential imbalance, we ponder the climatic factors which could alter the ratio of R:P, including antecedent soil moisture conditions, changes in soil moisture storage, changes in evapotranspiration (ET) rates or changes in precipitation intensity [27]. As the region is arid, it is unlikely that antecedent soil moisture conditions would vary greatly between episodic recharge events. ET rates could potentially change as a result of increased temperatures in the region [68]; however, as potential evapotranspiration (PET) greatly exceeds precipitation on an annual basis, it is unlikely that variability in ET would create a shift in the R:P ratio. To assess our hypothesis, we evaluated changes in the temporal mean and variance of the difference in monthly $\mathrm{P}$ and ET for regions around each well as simulated in the National Land Data Assimilation System (NLDAS) [69,70] model including NOAH [71], Variable Infiltration Capacity (VIC) [72] and MOSAIC [73]. The difference, P-ET, represents the flux of water between land and atmosphere. Thus, any significant change in P-ET would suggest that the changes in groundwater recharge could be due to portioning of water to streamflow, soil moisture or infiltration. Our results documented no significant change in P-ET for each 1/8-degree grid encompassing each well. Also, soil moisture likely decreases to levels below the wilting point as a result of high PET between rare episodic precipitation events. Thus, we anticipate that small changes in precipitation intensity, which can have a considerable impact on recharge [27] may result in a change in the R:P ratio. It is important to 
recognize that changes in groundwater storage, as evaluated in the MRC (Section 3.1) is not a factor in shifts in the R:P ratio as changes in $\mathrm{dh} / \mathrm{dt}$ have been accounted for prior to the estimation of recharge from the groundwater hydrograph.

\subsection{IDF Curves}

To evaluate the influence of precipitation intensity to alter recharge, IDF curves for return periods of 2, 5 and 10 years for 3-, 6-, 12-, 24-, 36- and 48-h precipitation duration events were estimated as illustrated in Figure 5. The IDF curves in Figure 5 illustrate precipitation behaviors either prior to the change in the R:P ratio (Section 4.2) or after the change. We can identify a change in precipitation intensity, especially for short (i.e., 2- and 5-year) return periods. To assess these apparent shifts in precipitation intensities, we evaluate the precipitation intensity magnification, which represents the factor by which the posterior precipitation intensity at a return interval would need to be multiplied by to obtain the preceding precipitation intensity. For example, a magnification factor of 0.5 for a 4 -year return period implies that the posterior precipitation intensity has been reduced by $50 \%$. The precipitation intensity magnification is defined as

$$
M_{p}=\frac{I_{p_{t n}}}{I_{p_{t c}}}
$$

where $I_{\mathrm{p}}$ is the intensity for precipitation while factors $t_{\mathrm{n}}$ and $\mathrm{t}_{\mathrm{c}}$ represent either posterior or preceding time, respectively. Results summarized in Table 2 suggest slight changes in precipitation intensity with magnification factors generally less than 1 for return periods of 2, 5 and 10 years. Such changes in precipitation intensity have been shown to dramatically alter recharge $[25,27,74]$. Magnification factors for several sites, Site E for example, exhibit reduced magnitudes for short-duration events and increased magnitude for longer-duration events. Such changes illustrate the importance of short-term and high intensity precipitation events in the region which typically result from summer monsoon events [75].
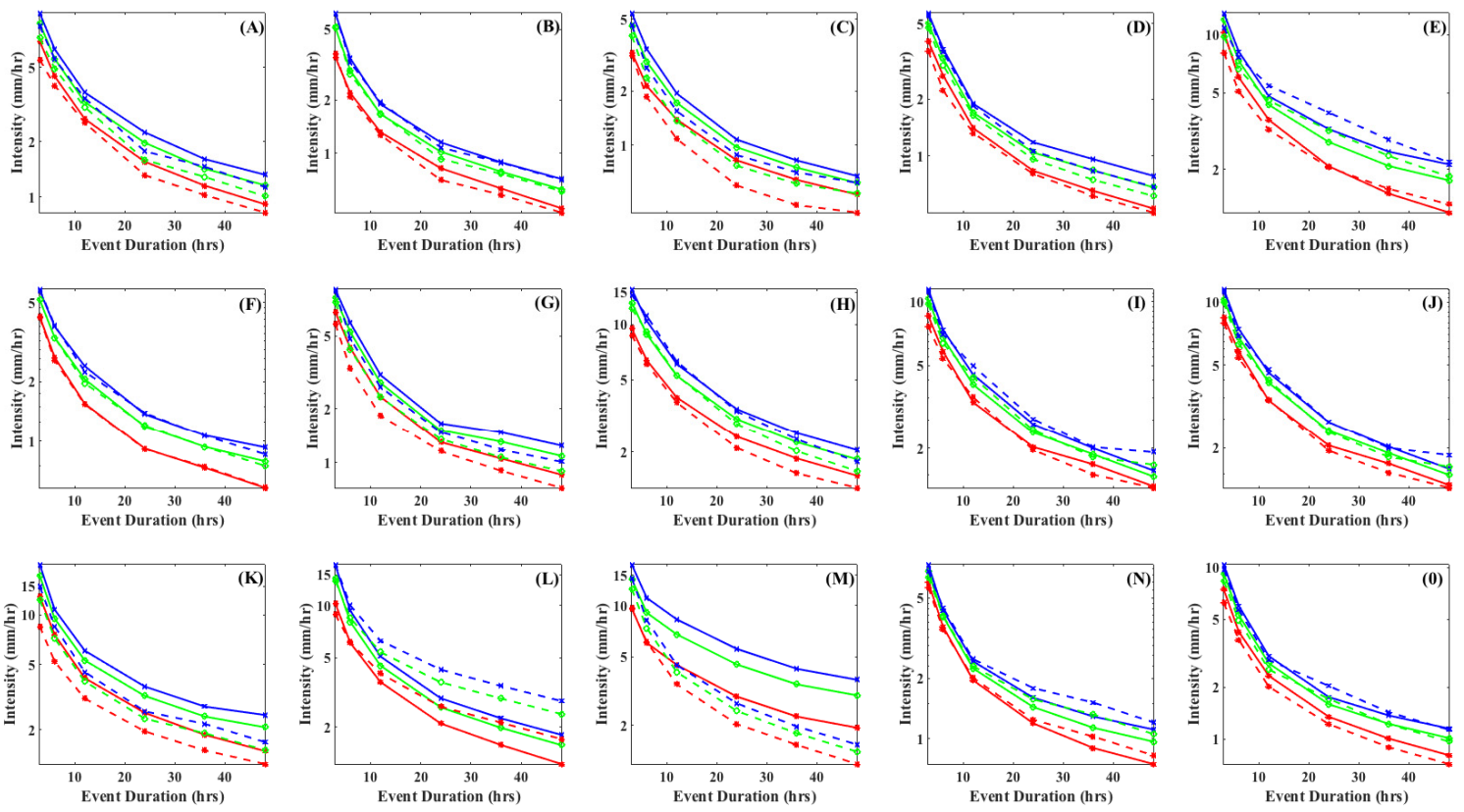

$\rightarrow$-2-yr Pre $\rightarrow-$-yr Pre $\rightarrow-10-y r$ Pre $\rightarrow \cdots-$ 2-yr Post

- 5-yr Post $\quad-*-10-y r$ Post

Figure 5. Intensity-Duration-Frequency curves preceding the change in the $\mathrm{R} / \mathrm{P}$ ratio (solid line) compared to posterior IDF curves for 3-, 6-, 12-, 24-, 36- and 48-h event durations. In general, the observed intensity for posterior precipitation events were lower than preceding precipitation events. 
Table 2. Precipitation intensity magnification as estimated using Equation (8).

\begin{tabular}{|c|c|c|c|c|c|c|c|c|c|c|c|c|c|c|c|}
\hline \multirow{2}{*}{ Duration } & \multicolumn{3}{|c|}{ Site A } & \multicolumn{3}{|c|}{ Site B } & \multicolumn{3}{|c|}{ Site C } & \multicolumn{3}{|c|}{ Site D } & \multicolumn{3}{|c|}{ Site E } \\
\hline & 2-year & 5-year & 10-year & 2-year & 5-year & 10-year & 2-year & 5-year & 10-year & 2-year & 5-year & 10-year & 2-year & 5-year & 10-year \\
\hline 3-h & 0.80 & 0.83 & 0.85 & 1.05 & 1.01 & 1.00 & 0.97 & 0.89 & 0.86 & 0.89 & 0.94 & 0.97 & 0.78 & 0.82 & 0.84 \\
\hline 6-h & 0.89 & 0.89 & 0.88 & 0.95 & 0.95 & 0.95 & 0.87 & 0.81 & 0.79 & 0.83 & 0.92 & 0.96 & 0.84 & 0.91 & 0.93 \\
\hline 12-h & 0.95 & 0.94 & 0.93 & 0.96 & 1.01 & 1.03 & 0.78 & 0.79 & 0.80 & 0.94 & 0.96 & 0.97 & 0.89 & 1.05 & 1.14 \\
\hline 24-h & 0.85 & 0.81 & 0.79 & 0.86 & 0.91 & 0.94 & 0.72 & 0.79 & 0.82 & 0.96 & 0.92 & 0.90 & 0.99 & 1.15 & 1.22 \\
\hline $36-h$ & 0.89 & 0.90 & 0.91 & 0.92 & 0.97 & 0.99 & 0.72 & 0.81 & 0.86 & 0.94 & 0.89 & 0.87 & 1.06 & 1.13 & 1.16 \\
\hline \multirow[t]{3}{*}{ 48-h } & 0.90 & 0.87 & 0.86 & 0.95 & 0.98 & 0.99 & 0.80 & 0.87 & 0.92 & 0.95 & 0.90 & 0.88 & 1.10 & 1.05 & 1.02 \\
\hline & \multicolumn{3}{|c|}{ Site F } & \multicolumn{3}{|c|}{ Site G } & \multicolumn{3}{|c|}{ Site H } & \multicolumn{3}{|c|}{ Site I } & \multicolumn{3}{|c|}{ Site J } \\
\hline & 2-year & 5-year & 10-year & 2-year & 5-year & 10-year & 2-year & 5-year & 10-year & 2-year & 5-year & 10-year & 2-year & 5-year & 10-year \\
\hline 3-h & 0.99 & 1.00 & 1.01 & 0.86 & 0.94 & 0.98 & 0.92 & 0.93 & 0.93 & 0.89 & 0.95 & 0.98 & 0.94 & 0.97 & 0.98 \\
\hline 6-h & 0.97 & 1.00 & 1.01 & 0.77 & 0.80 & 0.82 & 0.96 & 1.03 & 1.06 & 0.92 & 0.94 & 0.95 & 0.93 & 0.93 & 0.92 \\
\hline 12-h & 0.99 & 0.96 & 0.94 & 0.79 & 0.83 & 0.86 & 0.94 & 1.00 & 1.03 & 1.06 & 1.09 & 1.10 & 1.01 & 1.03 & 1.04 \\
\hline 24-h & 0.99 & 1.01 & 1.01 & 0.89 & 0.89 & 0.89 & 0.87 & 0.94 & 0.97 & 0.97 & 1.03 & 1.06 & 0.94 & 0.98 & 1.00 \\
\hline 36-h & 1.01 & 1.00 & 0.99 & 0.86 & 0.82 & 0.80 & 0.83 & 0.89 & 0.92 & 0.89 & 0.97 & 1.01 & 0.90 & 0.96 & 0.99 \\
\hline \multirow[t]{3}{*}{ 48-h } & 1.01 & 0.95 & 0.92 & 0.85 & 0.82 & 0.81 & 0.86 & 0.86 & 0.86 & 0.98 & 1.14 & 1.22 & 0.97 & 1.09 & 1.16 \\
\hline & \multicolumn{3}{|c|}{ Site K } & \multicolumn{3}{|c|}{ Site L } & \multicolumn{3}{|c|}{ Site $\mathbf{M}$} & \multicolumn{3}{|c|}{ Site $\mathbf{N}$} & \multicolumn{3}{|c|}{ Site $O$} \\
\hline & 2-year & 5-year & 10-year & 2-year & 5-year & 10-year & 2-year & 5 -year & 10-year & 2-year & 5 -year & 10-year & 2-year & 5-year & 10-year \\
\hline 3-h & 0.66 & 0.71 & 0.74 & 0.87 & 0.97 & 1.01 & 0.99 & 0.88 & 0.83 & 0.94 & 0.93 & 0.93 & 0.84 & 0.91 & 0.94 \\
\hline 6-h & 0.69 & 0.76 & 0.79 & 1.01 & 1.05 & 1.07 & 1.01 & 0.81 & 0.74 & 0.97 & 1.01 & 1.03 & 0.90 & 0.93 & 0.95 \\
\hline 12-h & 0.75 & 0.74 & 0.74 & 1.12 & 1.20 & 1.23 & 0.77 & 0.60 & 0.54 & 1.03 & 1.03 & 1.03 & 0.86 & 0.92 & 0.95 \\
\hline 24-h & 0.77 & 0.73 & 0.71 & 1.25 & 1.39 & 1.46 & 0.69 & 0.54 & 0.48 & 1.04 & 1.09 & 1.12 & 0.91 & 1.08 & 1.16 \\
\hline $36-\mathrm{h}$ & 0.80 & 0.79 & 0.78 & 1.34 & 1.47 & 1.53 & 0.68 & 0.52 & 0.46 & 1.14 & 1.16 & 1.17 & 0.89 & 0.99 & 1.04 \\
\hline 48-h & 0.83 & 0.73 & 0.68 & 1.39 & 1.51 & 1.56 & 0.61 & 0.47 & 0.42 & 1.10 & 1.09 & 1.09 & 0.89 & 0.95 & 0.98 \\
\hline
\end{tabular}




\section{Discussion}

The groundwater recharge literature has few studies that seek to characterize episodic recharge in arid regions. [76] studied episodic recharge in the Murray Darling basin, later identifying the nature of episodic recharge across the region [26]. Limited studies [26,28] have assessed in situ groundwater data to characterize changes in recharge. This study evaluated groundwater elevations within the arid southwestern United States to understand potential changes in recharge which may have led to decreases in groundwater storage which Castle et al. [31] and Konikow [67] identified within the Lower Colorado River basin and Arizona, respectively. Our results clearly document changes in the relationship between recharge and precipitation identified using the SPR analysis in the double mass curve (Figure 3). Further, the timing of the significant change in the R:P ratio occurred concurrent to noticeable changes in precipitation intensity identified by the precipitation magnification intensity index (Equation (8)). We thus attribute changes in the R:P ratio (Figure 4) to changes in precipitation intensity (Figure 5) across the region. Such results have been predicted for constant recharge sources [77] whereby changes to any of the water budget variables (here precipitation) can lead to changes in the infiltration of water to the saturated zone.

The episodic nature of groundwater recharge $[24,25]$ was evident in Figure 4 highlighted by the step pattern of recharge and precipitation in the double mass curve. Through a simple approach to isolate a change in the relation between recharge and precipitation, the SPR approach, we identified a significant shift in recharge behavior. Given the aridity of the region, we hypothesized that changes in precipitation intensity have altered recharge in the region. Based on the time of the observed change in the R:P ratio (Figure 2, Table 1), we isolated precipitation data to represent precipitation intensity before and after the event. An IDF analysis employing a metric to account for precipitation intensity, a precipitation intensity magnification, identified a slight decrease in intensity posterior to the change identified in the R:P ratio (Table 2, Figure 5). Our findings support previous studies which identified precipitation intensity as an important factor in groundwater recharge $[26,27,74,78]$ whereby small changes in precipitation intensity result in magnified changes in groundwater recharge. Thus, as argued by Alley and Konikow [32], a decrease in groundwater storage can, in part, be explained by a change in the recharge behaviors in wells across the southwestern United States. It remains unknown, however, if the apparent change in the precipitation intensity is a function of climate-scale variability [79] or climate change [80].

Groundwater resources in arid regions of the globe are considered nonrenewable [18] and under stress [11]; therefore, a full understanding of the factors by which stress is identified, primarily use (natural and anthropogenic) and availability (a function of both recharge and groundwater storage), is necessary to effectively and sustainably manage the resource. This study documents the fact that changes in precipitation intensity can result in a change in recharge behaviors, a factor of great importance for groundwater management [81-83]. The change in recharge behaviors was identified during a prolonged drought, thus illustrating the importance of climate variability for recharge resulting from La Nina/El Nino [84] or ENSO/PDO [85]. Reference [80] summarized global groundwater recharge studies over historical time frames, highlighting the need to understand recharge for sustainable groundwater management. Our study provides further evidence of the importance of characterizing groundwater recharge behaviors over short time periods which are affected by variability in precipitation statistics.

Acknowledgments: The authors wish to thank state water resource agencies in the study area for data access. The research was carried out at the Jet Propulsion Laboratory, California Institute of Technology, under a contract with the National Aeronautics and Space Administration. Support from the GRACE Science Team and the Jet Propulsion Laboratory Research and Technology Development programs is gratefully acknowledged.

Author Contributions: Brian F. Thomas conceived and designed the experiments, performed the analysis and analyzed the data, and Ali Behrangi provided guidance on use of TRMM data. All authors (Brian F. Thomas, Ali Behrangi and James S. Famiglietti) contributed to writing of the paper.

Conflicts of Interest: The authors declare no conflict of interest. 


\section{References}

1. Pandey, V.P.; Shrestha, S.; Chapagain, S.K.; Kazama, F. A framework for measuring groundwater sustainability. Environ. Sci. Policy 2011, 14, 396-407. [CrossRef]

2. Sophocleous, M. Groundwater recharge and sustainability in the High Plains aquifer in Kansas, USA. Hydrogeol. J. 2005, 13, 351-365. [CrossRef]

3. Theis, C.V. The source of water derived from wells. Civil Eng. 1940, 10, 277-280.

4. Thomas, B.F.; Famiglietti, J.S. Sustainable groundwater management in the arid Southwestern US: Coachella Valley, California. Water Resour. Manag. 2015, 29, 4411-4426. [CrossRef]

5. Sharda, V.N. Watershed Management and Water Harvesting as Strategic Tools for Groundwater Augmentation. Available online: http://publications.iwmi.org/pdf/H039314.pdf (accessed on 3 March 2016).

6. Bredehoeft, J.D. The water budget myth revisited: Why hydrogeologists model. Groundwater 2002, 40, 340-345. [CrossRef]

7. Alley, W.M.; Leake, S.A. The journey from safe yield to sustainability. Groundwater 2004, 42, 12-16. [CrossRef]

8. Zhou, Y. A critical review of groundwater budget myth, safe yield and sustainability. J. Hydrol. 2009, 370, 207-213. [CrossRef]

9. Döll, P.; Flörke, M. Global-Scale Estimation of Diffuse Groundwater Recharge: Model Tuning to Local Data for Semi-Arid and Arid Regions and Assessment of Climate Change Impact; Institute of Physical Geography, Frankfurt University: Frankfurt am Main, Germany, 2005.

10. Wada, Y.; van Beek, L.P.; van Kempen, C.M.; Reckman, J.W.; Vasak, S.; Bierkens, M.F. Global depletion of groundwater resources. Geophys. Res. Lett. 2010, 37. [CrossRef]

11. Richey, A.S.; Thomas, B.F.; Lo, M.H.; Reager, J.T.; Famiglietti, J.S.; Voss, K.; Swenson, S.; Rodell, M. Quantifying renewable groundwater stress with GRACE. Water Resour. Res. 2015, 51, 5217-5238. [CrossRef] [PubMed]

12. Loáiciga, H.A.; Maidment, D.R.; Valdes, J.B. Climate-change impacts in a regional karst aquifer, Texas, USA. J. Hydrol. 2000, 227, 173-194. [CrossRef]

13. York, J.P.; Person, M.; Gutowski, W.J.; Winter, T.C. Putting aquifers into atmospheric simulation models: An example from the Mill Creek Watershed, northeastern Kansas. Adv. Water Resour. 2002, 25, 221-238. [CrossRef]

14. Allen, D.M.; Mackie, D.C.; Wei, M. Groundwater and climate change: A sensitivity analysis for the Grand Forks aquifer, southern British Columbia, Canada. Hydrogeol. J. 2004, 12, 270-290. [CrossRef]

15. Hughes, D.A. Incorporating groundwater recharge and discharge functions into an existing monthly rainfall-runoff model/Incorporation de fonctions de recharge et de vidange superficielle de nappes au sein d'un modèle pluie-débit mensuel existant. Hydrol. Sci. J. 2004, 49. [CrossRef]

16. Green, T.R.; Bates, B.C.; Charles, S.P.; Fleming, P.M. Physically based simulation of potential effects of carbon dioxide-altered climates on groundwater recharge. Vadose Zone J. 2007, 6, 597-609. [CrossRef]

17. Crosbie, R.S.; McCallum, J.L.; Walker, G.R.; Chiew, F.H. Modelling climate-change impacts on groundwater recharge in the Murray-Darling Basin, Australia. Hydrogeol. J. 2010, 18, 1639-1656. [CrossRef]

18. Margat, J.; Van der Gun, J. Groundwater around the World: A Geographic Synopsis; CRC Press: Boca Raton, FL, USA, 2013.

19. Kløve, B.; Ala-Aho, P.; Bertrand, G.; Gurdak, J.J.; Kupfersberger, H.; Kværner, J.; Muotka, T.; Mykrä, H.; Preda, E.; Rossi, P.; et al. Climate change impacts on groundwater and dependent ecosystems. J. Hydrol. 2014, 518, 250-266. [CrossRef]

20. Famiglietti, J.S. The global groundwater crisis. Nat. Clim. Chang. 2014, 4, 945-948. [CrossRef]

21. Konikow, L.F. Contribution of global groundwater depletion since 1900 to sea-level rise. Geophys. Res. Lett. 2011, 38. [CrossRef]

22. Voss, C.I.; Soliman, S.M. The transboundary non-renewable Nubian Aquifer System of Chad, Egypt, Libya and Sudan: Classical groundwater questions and parsimonious hydrogeologic analysis and modeling. Hydrogeol. J. 2014, 22, 441-468. [CrossRef]

23. Hashemi, H.; Uvo, C.B.; Berndtsson, R. Coupled modeling approach to assess climate change impacts on groundwater recharge and adaptation in arid areas. Hydrol. Earth Syst. Sci. 2015, 19, 4165-4181. [CrossRef] 
24. Gee, G.W.; Hillel, D. Groundwater recharge in arid regions: Review and critique of estimation methods. Hydrol. Process. 1988, 2, 255-266. [CrossRef]

25. Lewis, F.M.; Walker, G.R. Assessing the potential for significant and episodic recharge in southwestern Australia using rainfall data. Hydrogeol. J. 2002, 10, 229-237. [CrossRef]

26. Crosbie, R.S.; McCallum, J.L.; Walker, G.R.; Chiew, F.H. Episodic recharge and climate change in the Murray-Darling Basin, Australia. Hydrogeol. J. 2012, 20, 245-261. [CrossRef]

27. Barron, O.V.; Crosbie, R.S.; Dawes, W.R.; Charles, S.P.; Pickett, T.; Donn, M.J. Climatic controls on diffuse groundwater recharge across Australia. Hydrol. Earth Syst. Sci. 2012, 16, 4557-4570. [CrossRef]

28. Nimmo, J.R.; Horowitz, C.; Mitchell, L. Discrete-Storm Water-Table Fluctuation Method to Estimate Episodic Recharge. Groundwater 2015, 53, 282-292. [CrossRef] [PubMed]

29. Piechota, T.; Timilsena, J.; Tootle, G.; Hidalgo, H. The western US drought: How bad is it? Eos Trans. Am. Geophys. Union 2004, 85, 301-304. [CrossRef]

30. Cayan, D.R.; Das, T.; Pierce, D.W.; Barnett, T.P.; Tyree, M.; Gershunov, A. Future dryness in the southwest US and the hydrology of the early 21st century drought. Proc. Natl. Acad. Sci. USA 2010, 107, 21271-21276. [CrossRef] [PubMed]

31. Castle, S.L.; Thomas, B.F.; Reager, J.T.; Rodell, M.; Swenson, S.C.; Famiglietti, J.S. Groundwater depletion during drought threatens future water security of the Colorado River Basin. Geophys. Res. Lett. 2014, 41, 5904-5911. [CrossRef] [PubMed]

32. Alley, W.M.; Konikow, L.F. Bringing GRACE down to earth. Groundwater 2015, 53, 826-829. [CrossRef] [PubMed]

33. Alley, W.M.; La Baugh, J.W.; Reilly, T.E. Groundwater as an element in the hydrological cycle. Encycl. Hydrol. Sci. 2005. [CrossRef]

34. Siebert, S.; Burke, J.; Faures, J.M.; Frenken, K.; Hoogeveen, J.; Döll, P.; Portmann, F.T. Groundwater use for irrigation-A global inventory. Hydrol. Earth Syst. Sci. 2010, 14, 1863-1880. [CrossRef]

35. Trenberth, K.E.; Dai, A.; Rasmussen, R.M.; Parsons, D.B. The changing character of precipitation. Bull. Am. Meteorol. Soc. 2003, 84, 1205-1217. [CrossRef]

36. Searcy, J.K.; Hardison, C.H. Double-Mass Curves; U.S. Government Printing Office: Washington, DC, USA, 1960.

37. Huffman, G.J.; Bolvin, D.T.; Nelkin, E.J.; Wolff, D.B.; Adler, R.F.; Gu, G.; Stocker, E.F. The TRMM multisatellite precipitation analysis (TMPA): Quasi-global, multiyear, combined-sensor precipitation estimates at fine scales. J. Hydrometeorol. 2007, 8, 38-55. [CrossRef]

38. Schneider, U.; Becker, A.; Finger, P.; Meyer-Christoffer, A.; Rudolf, B.; Ziese, M. GPCC Full Data Reanalysis Version 7.0 At 2.5deg: Monthly Land-Surface Precipitation from Rain-Gages Built on GTS-based and Historic Data; Global Precipitation Climatology Centre: Boulder, CO, USA, 2015.

39. Behrangi, A.; Khakbaz, B.; Jaw, T.C.; AghaKouchak, A.; Hsu, K.; Sorooshian, S. Hydrologic evaluation of satellite precipitation products over a mid-size basin. J. Hydrol. 2011, 397, 225-237. [CrossRef]

40. Wall, C.L.; Zipser, E.J.; Liu, C. A regional climatology of monsoonal precipitation in the southwestern United States using TRMM. J. Hydrometeorol. 2012, 13, 310-323. [CrossRef]

41. $\mathrm{Xu}, \mathrm{W}$; Zipser, E.J. Properties of deep convection in tropical continental, monsoon, and oceanic rainfall regimes. Geophys. Res. Lett. 2012, 39. [CrossRef]

42. U.S. Geological Survey. USGS Water Data for the Nation. Available online: http://waterdata.usgs.gov/nwis (accessed on 7 March 2016).

43. Arizona Department of Water Resources. Groundwater Site Inventory. Available online: http:/ /gisweb.azwater.gov/waterresourcesdata/gwsi.aspx (accessed on 7 March 2016).

44. Vogel, R.M.; Kroll, C.N. Regional geohydrologic-geomorphic relationships for the estimation of low-flow statistics. Water Resour. Res. 1992, 28, 2451-2458. [CrossRef]

45. Thomas, B.F.; Vogel, R.M.; Kroll, C.N.; Famiglietti, J.S. Estimation of the base flow recession constant under human interference. Water Resour. Res. 2013, 49, 7366-7379. [CrossRef]

46. Healy, R.W.; Cook, P.G. Using groundwater levels to estimate recharge. Hydrogeol. J. 2002, 10, 91-109. [CrossRef]

47. Heppner, C.S.; Nimmo, J.R. A computer program for predicting recharge with a master recession curve. US Geological Survey: Menlo Park, CA, USA, 2005. 
48. Olmsted, F.H.; Hely, A.G. Relation between Ground Water and Surface Water in Brandywine Creek Basin, Pennsylvania (No. 417-A); U.S. Government Printing Office: Washington, DC, USA, 1962.

49. Risser, D.W.; Gburek, W.J.; Folmar, G.J. Comparison of recharge estimates at a small watershed in east-central Pennsylvania, USA. Hydrogeol. J. 2009, 17, 287-298. [CrossRef]

50. Merriam, C.F. A comprehensive study of the rainfall on the Susquehanna Valley. Eos Trans. Am. Geophys. Union 1937, 18, 471-476. [CrossRef]

51. Lee, C.H.; Chen, W.P.; Lee, R.H. Estimation of groundwater recharge using water balance coupled with base-flow-record estimation and stable-base-flow analysis. Environ. Geol. 2006, 51, 73-82. [CrossRef]

52. Stedinger, J.R.; Vogel, R.M.; Foufoula-Georgiou, E. Frequency Analysis of Extreme Events; U.S. Government Printing Office: Washington, DC, USA, 1993.

53. Smith, J.A. Precipitation, Handbook of Hydrology; McGraw-Hill, Inc.: New York, NY, USA, 1993; Volume 3.

54. McCuen, R.H. Hydrologic Design and Analysis; Prince Hall: New Jersey, NJ, USA, 1998; Volume 814.

55. Chow, V.T.; Maidment, D.R.; Mays, L.W. Applied Hydrology; McGraw-Hill: New York, NY, USA, 1988.

56. Dingman, S.L. Physical Hydrology; Waveland Press: Long Grove, IL, USA, 2015.

57. Koutsoyiannis, D. Statistics of extremes and estimation of extreme rainfall: I. Theoretical investigation/Statistiques de valeurs extrêmes et estimation de précipitations extrêmes: I. Recherche théorique. Hydrol. Sci. J. 2004, 49. [CrossRef]

58. Gumbel, E.J. Statistics of Extremes; Courier Corporation: New York, NY, USA, 2012.

59. Cuanne, C. Unbiased plotting positions-A review. J. Hydrol. 1987, 37, 205-222. [CrossRef]

60. Hosking, J.R.M. Algorithm AS 215: Maximum-likelihood estimation of the parameters of the generalized extreme-value distribution. Appl. Stat. 1985, 34, 301-310. [CrossRef]

61. Dourte, D.; Shukla, S.; Singh, P.; Haman, D. Rainfall intensity-duration-frequency relationships for Andhra Pradesh, India: Changing rainfall patterns and implications for runoff and groundwater recharge. J. Hydrol. Eng. 2012, 18, 324-330. [CrossRef]

62. Wang, H.; Gao, J.E.; Zhang, M.J.; Li, X.H.; Zhang, S.L.; Jia, L.Z. Effects of rainfall intensity on groundwater recharge based on simulated rainfall experiments and a groundwater flow model. Catena 2015, 127, 80-91. [CrossRef]

63. Camera, C.; Masetti, M.; Apuani, T. Rainfall, infiltration, and groundwater flow in a terraced slope of Valtellina (Northern Italy): Field data and modelling. Environ. Earth Sci. 2012, 65, 1191-1202. [CrossRef]

64. Machusick, M.; Welker, A.; Traver, R. Groundwater mounding at a storm-water infiltration BMP. J. Irrig. Drain. Eng. 2011, 137, 154-160. [CrossRef]

65. Rutledge, A.T. Computer Programs for Describing the Recession of Ground-Water Discharge and for Estimating Mean Ground-Water Recharge and Discharge from Streamflow Records: Update; US Department of the Interior: Washington, DC, USA; US Geological Survey: Reston, VA, USA, 1998.

66. Posavec, K.; Bačani, A.; Nakić, Z. A visual basic spreadsheet macro for recession curve analysis. Groundwater 2006, 44, 764-767. [CrossRef] [PubMed]

67. Konikow, L.F. Groundwater Depletion in the United States (1900-2008); US Department of the Interior: Washington, DC, USA; US Geological Survey: Reston, VA, USA, 2013; p. 63.

68. Dobrowski, S.Z.; Abatzoglou, J.; Swanson, A.K.; Greenberg, J.A.; Mynsberge, A.R.; Holden, Z.A.; Schwartz, M.K. The climate velocity of the contiguous United States during the 20th century. Glob. Chang. Biol. 2013, 19, 241-251. [CrossRef] [PubMed]

69. Mitchell, K.E.; Lohmann, D.; Houser, P.R.; Wood, E.F.; Schaake, J.C.; Robock, A.; Cosgrove, B.A.; Sheffield, J.; Duan, Q.; Luo, L.; et al. The multi-institution North American Land Data Assimilation System (NLDAS): Utilizing multiple GCIP products and partners in a continental distributed hydrological modeling system. J. Geophys. Res. Atmos. 2004, 109. [CrossRef]

70. Xia, Y.; Mitchell, K.; Ek, M.; Cosgrove, B.; Sheffield, J.; Luo, L.; Alonge, C.; Wei, H.; Meng, J.; Livneh, B.; et al. Continental-scale water and energy flux analysis and validation for North American Land Data Assimilation System project phase 2 (NLDAS-2): 2. Validation of model-simulated streamflow. J. Geophys. Res. Atmos. 2012, 117. [CrossRef]

71. Koren, V.; Schaake, J.; Mitchell, K.; Duan, Q.Y.; Chen, F.; Baker, J.M. A parameterization of snowpack and frozen ground intended for NCEP weather and climate models. J. Geophys. Res. Atmos. 1999, 104, 19569-19585. [CrossRef] 
72. Liang, X.; Lettenmaier, D.P.; Wood, E.F.; Burges, S.J. A simple hydrologically based model of land surface water and energy fluxes for general circulation models. J. Geophys. Res. All Ser. 1994, 99, 14415-14428. [CrossRef]

73. Koster, R.D.; Suarez, M.J. Modeling the land surface boundary in climate models as a composite of independent vegetation stands. J. Geophys. Res. 1992, 97. [CrossRef]

74. French, R.H.; Jacobson, R.L.; Lyles, B.F. Threshold precipitation events and potential ground-water recharge. J. Hydr. Eng. 1996, 122, 573-578. [CrossRef]

75. Mock, C.J. Climatic controls and spatial variations of precipitation in the western United States. J. Clim. 1996, 9,1111-1125. [CrossRef]

76. Crosbie, R.S.; Dawes, W.R.; Charles, S.P.; Mpelasoka, F.S.; Aryal, S.; Barron, O.; Summerell, G.K. Differences in future recharge estimates due to GCMs, downscaling methods and hydrological models. Geophys. Res. Lett. 2011, 38. [CrossRef]

77. McCallum, J.L.; Crosbie, R.S.; Walker, G.R.; Dawes, W.R. Impacts of climate change on groundwater in Australia: A sensitivity analysis of recharge. Hydrogeol. J. 2010, 18, 1625-1638. [CrossRef]

78. Kendy, E.; Zhang, Y.; Liu, C.; Wang, J.; Steenhuis, T. Groundwater recharge from irrigated cropland in the North China Plain: Case study of Luancheng County, Hebei Province, 1949-2000. Hydrol. Process. 2004, 18, 2289-2302. [CrossRef]

79. Griffin, D.; Woodhouse, C.A.; Meko, D.M.; Stahle, D.W.; Faulstich, H.L.; Carrillo, C.; Leavitt, S.W. North American monsoon precipitation reconstructed from tree-ring latewood. Geophys. Res. Lett. 2013, 40, 954-958. [CrossRef]

80. Cook, B.I.; Seager, R. The response of the North American Monsoon to increased greenhouse gas forcing. J. Geophys. Res. Atmos. 2013, 118, 1690-1699. [CrossRef]

81. Gleick, P.H. Water in crisis: Paths to sustainable water use. Ecol. Appl. 1998, 8, 571-579. [CrossRef]

82. Scanlon, B.R.; Keese, K.E.; Flint, A.L.; Flint, L.E.; Gaye, C.B.; Edmunds, W.M.; Simmers, I. Global synthesis of groundwater recharge in semiarid and arid regions. Hydrol. Process. 2006, 20, 3335-3370. [CrossRef]

83. Pietersen, K. Multiple criteria decision analysis (MCDA): A tool to support sustainable management of groundwater resources in South Africa. Water SA 2007, 32, 119-128. [CrossRef]

84. McCabe, G.J.; Dettinger, M.D. Decadal variations in the strength of ENSO teleconnections with precipitation in the western United States. Int. J. Climatol. 1999, 19, 1399-1410. [CrossRef]

85. Cayan, D.R.; Redmond, K.T.; Riddle, L.G. ENSO and hydrologic extremes in the western United States*. J. Clim. 1999, 12, 2881-2893. [CrossRef] 